\title{
Antara Semangat Pengabdian dan Keterbatasan Diri: Studi Fenomenologi tentang Stres Kerja Perawat yang Bertugas di Ruang Intensif dan Isolasi COVID-19
}

\section{Between Dedication and Self-limitedness : Phenomenology Study about Stres related Work among Nurses that are Working at Intensive Care and Isolation Room of COVID-19}

\author{
Hidayati Hidayati, Winarini Wilman Mansoer \\ Fakultas Psikologi, Universitas Indonesia, Depok, Indonesia \\ Email: hidayati81@ui.ac.id; winarini.d@ui.ac.id
}

\section{KATA KUNCI COVID 19, Perawat, Stres Kerja. \\ KEYWORDS COVID-19, Nurses, Stres related Work.}

ABSTRAK

Penelitian ini menggunakan pendekatan fenomenologi dan bertujuan untuk memahami pengalaman perawat di ruang intensif yang rentan mengalami distres psikologis dan bagaimana mereka memaknai pengalamannya. Masih sedikit penelitian yang mencoba untuk menggali lebih dalam mengenai kondisi psikologis perawat dilihat dari sisi pengalaman subjektif. Pengumpulan data dilakukan dengan wawancara mendalam terhadap tiga orang perawat. Hasil penelitian ini menunjukkan terdapat beberapa tema yang sama antar partisipan terkait dengan pengalaman mereka di ruang intensif dan ruang isolasi COVID19 seperti adanya rasa cemas, pekerjaan yang melelahkan. Tema yang muncul sebagian besar mengandung emosi negatif dan distres psikologis yang dialami selama bertugas dalam konteks yang beragam antar partisipan. Terlepas dari emosi negatif, terdapat sikap positif yang menjadi motivasi mereka untuk tetap mengabdi. Penelitian ini mengungkapkan secara spesifik tantangan unik yang dialami oleh partisipan dan dampaknya terhadap kesehatan mental mereka yang tidak dapat dijelaskan melalui penelitian kuantitatif.

ABSTRACT This study uses a phenomenological approach and aims to perceive nurses' experiences in the intensive room which has vulnerable to have psychological distress and how they interpret their experiences. There are limited studies that reveal about psychological distress from nurse's subjective view. Data is collected through a depth of interviews with three new nurses, who are on duty in intensive care room and a nurse in the COVID-19 isolation room, who has also served in the ICU. The result of this study shows some similar themes about their experiences in intensive care and COVID-19 isolation room such as anxiety and exhausting job. Majority of theme contain 
negative emotion and psychological distress while on duty in special context among participants. Regardless negative emotion dominated, positive attitude that encourage instrinsic motivation to serve patiens live. The study revealed specific challenge and experience among participants and how affect their mental health which not revealed from quantitative study.

\section{PENDAHULUAN}

Perawat merupakan salah satu tenaga medis yang bertugas memberikan tugas meliputi pemberian asuhan keperawatan dan sebagai konselor kepada pasien (Kemenkes, 2014). Lebih lanjut, hal ini bertujuan untuk memenuhi kebutuhan dan kemandirian klien dalam merawat dirinya (’ UU Keperawatan RI pasal 3 ayat 5).,

Profesi perawat dikatakan sebagai helping profession karena pekerjaannya berupa pemberian layanan kepada masyarakat yang fokus kepada pencegahan, penyembuhan dan mempertahankan komitmen untuk meningkatkan kualitas hidup dari populasi yang menerima pelayanan (NOHS dalam Neukrug, 2011). Dengan gambaran tersebut, perawat dianggap sebagai "white angel" karena selalu memberikan pertolongan dan bantuan demi kesembuhan pasien (Wang dkk., 2015) Pandangan tersebut juga didukung dengan gambaran tugas utama dari profesi perawat yaitu bertanggung jawab secara sosial dalam mempromosikan dan membantu memenuhi kebutuhan masyarakat untuk mendapatkan akses kesehatan. Studi yang dilakukan oleh Faseleh-Jahromi dkk. (2014) menunjukkan bahwa secara umum merawat dipandang sebagai profesi yang profesi yang selalu membangun hubungan baik, menjujung nilai kemanusiaan dan memberikan harapan kesembuhan kepada pasien tanpa memandang status sosial pasien. Namun demikian, terkadang persepsi tersebut tidak selalu dijumpai dalam praktek lapangan. Sikap yang tidak menunjukkan rasa empati dan kepedulian juga dapat ditemui pada perawat. Hal tersebut seringkali disebabkan oleh beban pekerjaan yang besar, jumlah staf yang tidak memadai, dan ketidakmampuan untuk megelola dampak psikologis dari pekerjaan (Tajvar dkk., 2015)

Dalam menjalankan pekerjaannya, perawat tidak jarang dihadapkan pada rasa sakit dan kematian pasien dimana jika tidak dikelola dengan baik akan berdampak pada kondisi psikologis mereka (Wang dkk., 2015a). Tidak hanya itu, tingginya tekanan, tuntutan kerja, dan kondisi yang tidak pasti membuat perawat seringkali melaporkan distres yang cukup tinggi, terutama bagi perawat yang bekerja di ruang intensif Trousselard dkk. (2016) ini dikarenakan kondisi pasien yang ditempatkan di ruang intensif memiliki harapan hidup yang rendah dan lebih dari $50 \%$ diantaranya meninggal (Croeger, 1999, dalam Hamric \& Blackhall, 2007).

Ketidakpastian kondisi pasien yang berada pada tahap kritis, membuat perawat yang bekerja di ruang intensif harus memiliki analisa yang tajam agar dapat memberikan penanganan yang baik. Mereka juga harus menaruh perhatian yang lebih pada informasi kecil, dimana hal ini membutuhkan proses kognitif yang rumit (Trousselard dkk., 2016). Hal ini seringkali membuat mereka kewalahan dan merasa lelah karena harus selalu fokus. Beratnya tanggung jawab dan kondisi kerja yang tidak begitu baik, tidak jarang membuat mereka mengalami kesulitan untuk mengambil keputusan yang tepat (Pradas-Hernández dkk., 2018). Mereka juga mengalami kesulitan untuk membuat keputusan terutama saat pasien berada dalam kondisi kritis karena tidak memiliki otonomi dan harus menunggu keputusan dokter. Menurut Myhren dkk., (2013) tidak adanya otonomi dalam membuat keputusan yang tepat menjadi salah satu hal yang berkontribusi dalam rendahnya kepuasan kerja. Myhren 
dkk. (2013) juga menambahkan bahwa dibandingkan dengan dokter.

Kepuasan kerja yang rendah, stres, dan sering berada pada kondisi yang tidak pasti membuat perawat rentan mengalami masalah psikologis dan burn out pada menjadi isu yang seringkali menjadi perhatian untuk diteliti (Myhren dkk., 2013; Wang dkk., 2015a). Hal ini disebabkan oleh salah satu ciri khas burn out adalah menurunnya rasa empati, dimana sikap empati merupakan salah satu hal yang diasah saat menjadi perawat. Gejala burn out yang muncul meliputi kelelahan, depresi, anxiety, dan gangguan tidur (Pradas-Hernández dkk., 2018). Pada kondisi yang lebih serius burn out menyebabkan hilangnya empati pada seseorang dikarenakan adanya kelelahan secara emosional (Pradas-Hernández dkk., 2018). Hal ini tampak berseberangan dengan pekerjaan perawat secara umum, dimana perawatan, memberikan perhatian dan dukungan emosional kepada pasien merupakan inti dari pekerjaan mereka. Kemungkinan hal ini dapat menjadi konflik batin antara melaksanakan kewajiban memberikan perawatan dengan penuh empati dengan hanya sekedar memberikan perawatan tanpa mampu memahami kesulitan yang dialami pasien.

Selain itu, sama halnya dengan tenaga medis lainnya, menjadi perawat juga berarti harus berani mengambil risiko akan paparan penyakit menular terutama saat wabah. Stone dkk. (2004) menemukan bahwa saat terjadinya wabah SARS kelompok yang banyak mengalami penularan salah satunya adalah perawat. Saat terjadi wabah para-influenza sekitar 65 staf perawat mengalami gejala kesulitan bernafas. Tidak hanya penularan melalui udara, penularan dari jarum suntik pun turut berkontribusi pada keselamatan diri mereka. Kondisi kerja yang sangat padat membuat mereka berisiko terkena darah yang terkontaminasi virus sehingga berdampak buruk pada kesehatan. Hal ini dapat menyebabkan munculnya risiko memburuknya kesehatan mental serta pada tingkat yang lebih serius bagi perawat terutama perawat baru yang masin minih dengan pengalaman sehingga dapat mengembangkan gejala PTSD (Adriaenssens dkk., 2012).

Pada tahun 2020 pandemi COVID19 menjadi masalah serius bagi kesehatan mental tenaga medis salah satunya perawat. Perawat yang kesehariannya bekerja di layanan kesehatan memiliki risiko besar tertular dan dapat berdampak pada kehilangan nyawa. Berdasarkan data dari Persatuan Perawat Nasional Indonesia (PPNI), hingga Mei 2020 di Indonesia terdapat sekitar 20 orang perawat yang meninggal karena tertular dan lebih dari 100 orang dinyatakan positif COVID-19 (Mantalean, 2020).

Secara kuantitatif banyak penelitian yang mengulas mengenai buruknya kesehatan mental perawat, tapi sangat sedikit penelitian baik secara kuantitatif maupun kualitatif yang menjelaskan alasan positif perawat masih bersedia untuk mengabdi. Adanya pandangan positif seperti bertambahnya pengalaman, variasi pekerjaan, serta rasa puas terhadap kewajiban dapat menjadi kepuasan tersendiri bagi mereka. Selain itu, dihadapkan pada berbagai pengalaman kerja dan adanya persepsi mencapai suatu pencapain tertentu dapat kemampuan mendorong meningkatnya self-efficacy pada individu (Hoff dkk., 2019). Namun demikian, sikap positif yang berkembang diantara para pelaku profesi perawat masih sangat jarang menjadi perhatian penelitian hingga saat ini.

Dengan memahami sikap positif di kalangan perawat atas profesinya, dapat dijadikan kekuatan dan faktor yang membuat mereka lebih resilens dalam menghadapi kesulitan dan tantangan di tempat kerja Pendekatan kuantitatif tidak memberikan gambaran secara personal mengenai bagaimana emosi, pikiran serta pemaknaan mendalam terhadap profesi yang mereka jalani. Sehubungan dengan hal di atas, penelitian ini bertujuan untuk memahami kondisi mental yang dilihat dari penghayatan perawat yang bekerja di ruang 
intensif dan perawat yang ditugaskan untuk menangani pasien COVID-19 serta motivasi mereka untuk tetap mengabdi.

\section{METODE PENELITIAN Pendekatan}

Penelitian ini menggunakan metode kualitatif dengan pendekatan fenomenologi yang bertujuan untuk memahami pengalaman dan pemaknaan individu terhadap suatu fenomena. Metode ini menghindari interpretasi dari peneliti dan lebih kepada memberikan gambaran pada pengalaman yang dialami oleh partisipan (Creswell dkk., 2007).

\section{Partisipan}

Subjek penelitian merupakan perawat yang bekerja di bidang kegawat daruratan khususnya HCU ataupun ICU serta yang bekerja di ruang isolasi COVID19. Jumlah partisipan pada penelitian adalah sebanyak tiga orang.

\section{Prosedur Penelitian}

Partisipan direkrut dengan metode purposive sampling agar memperoleh informasi yang sesuai dengan tujuan dari studi. Perekrutan partisipan dilakukan dengan menghubungi perawat yang pernah bekerja di ruang intensif meliputi HCU dan ICU dan bersedia untuk diwawancara. Satu perawat pernah bertugas di ICU dan saat ini sedang ditugaskan di ruang isolasi COVID19.

Data dikumpulkan melalui wawancara mendalam terhadap semua partisipan. Setiap partisipan diberi nama samaran untuk menjaga kerahasiaan identitas. Sebelum dilakukan wawancara, peneliti meminta kesediaan partisipan dengan memberikan inform concent sebagai bukti bahwa partisipan dengan sukarela memilki intensi untuk berpartisipasi. Sebelum wawancara dilakukan peneliti meminta kesediaan partisipan bahwa selama sesi wawancara akan direkam dengan menggunakan alat perekam dan dituliskan secara verbatim dengan tujuan tidak mengubah makna dari jawaban partisipan dan dibuat dalam bentuk transkrip.

\section{Metode Pengumpulan Data}

Dalam pengumpulan data digunakan wawancara mendalam dengan menggunakan teknik wawancara tidak terstruktur. Secara garis besar hal yang ditanyakan dalam wawancara adalah pemaknaan partisipan terhadap pekerjaannya, emosi-emosi yang dirasakan saat menghadapi pasien yang seharusnya bisa diselamatkan namun tidak selamat karena alasan lain, bagaimana partisipan mengatur stres karena jam kerja yang panjang dan hal yang dilakukan saat kehilangan empati ketika bekerja di area yang memberikan pertolongan. Hal ini bertujuan agar partisipan lebih bebas untuk mengungkapkan dan menggambarkan pengalamannya.

\section{Teknik Analisis Data}

Analisis data dilakukan dengan menggunakan langkah-langkah analisis fenomenologi (Langdridge, 2007). Pertama, peneliti melakukan analisis terhadap hasil transkrip dan fokus pada pengalaman yang menjadi fokus dari analisis. Peneliti melakukan dengan metode epoche, dimana hasil wawancara dilihat dari sudut objektif. Kedua, hasil dari transkrip dipecah menjadi unit yang lebih kecil dengan mengkaji konten pengalaman yang berhubungan dengan masalah-masalah yang tepat untuk diinvestigasi secara psikologis sehingga orang lain akan merasakan emosi, keyakinann dan perilaku dari partisipan. Ketiga, menganalisa makna dari unit tersebut terhadap signifikansinya secara psikologis dimana detil yang unik menjadi makna yang lebih umum. Keempat, melakukan sintesis terhadap makna dari unit psikologis dan mengidentifikasi elemen kunci dari fenomena yang digambarkan dari setiap partisipan. Selain itu juga diidentifikasi variasi antar partisipan. 
ANALISIS DAN HASIL

\section{Gambaran Umum Partisipan Partisipan 1 (Ade)}

Partisipan pertama dengan nama disamarkan sebagai Ade berusia 24 tahun. Sekarang ia bekerja sebagai perawat di Rumah Sakit X. Ia adalah seorang perawat yang telah menyelesaikan pendidikan profesi keperawatannya di salah satu perguruan tinggi negeri pada awal tahun 2018 lalu. Di RS X ia telah bekerja selama 7 bulan dan ditempatkan di ruangan Intensive Care Unit (ICU) dari awal bergabung di rumah sakit tersebut.

\section{Partisipan 2 (Bia)}

Partisipan kedua adalah Bia (nama disamarkan), berusia 24 tahun. Ia adalah perawat yang bekerja di Rumah Sakit K. Ia telah bekerja disana selama 11 bulan terhitung sejak akhir tahun 2017. Sebelum bekerja, partisipan menyelesaikan pendidikan profesinya di salah satu perguruan tinggi negeri. Ia ditempatkan di bagian Hygine Unit Care (HCU). HCU merupakan ruangan perawatan intensif yang levelnya di bawah ICU.Ia telah bekerja di ruangan tersebut selama 3 bulan.

\section{Partisipan 3 Cita)}

Partisipan ketiga adalah Cita (nama disamarkan), berusia 24 tahun, bekerja sebagai perawat di sebuah rumah sakit swasta. Ia pernah memiliki pengalaman bekerja di ruang intensive care. Saat dilakukan wawancara, partisipan sedang diperbantukan di ruang isolasi RSUD untuk menjadi perawat di ruang isolasi untuk pasien COVID-19

\section{Tema Antar Partisipan \\ Motivasi menjadi Perawat}

Partisipan memandang bahwa menjadi perawat bukanlah impian mereka. Keputusan menjadi perawat merupakan motivasi ekternal. Ade dan Cita mengungkapkan bahwa mereka melakukan hal tersebut demi memenuhi harapan orang tua. Mereka memiliki keinginan untuk menyenangkan hati orang tua. Restu dan izin dari orang tua dianggap sebagai hal yang utama dalam meraih kesuksesan

\begin{abstract}
Ayahku, sebenernya dia pengen anaknya jadi perawat. Tapi saat aku lulus, trus beneran mau jadi perawat eh beliaunya udah ga ada. Jadi pengen aja jadi perawat yang benar. Pasti ayahku melihat di suatu tempat (Ade).
\end{abstract}

Awalnya saya karena org tua. Saya ingin ambil teknik, tapi berhubung orang tua ga setuju, saya disuruh jadi perawat karena dulu ibu ingin jadi perawat tapi ga jadi. Bagi saya restu orang tua, restu Gusti Allah (Cita).

Di sisi lain Bia mengungkapkan bahwa dirinya memang memiliki keinginan untuk bekerja di bidang kesehatan karena latar belakang keluarga sebagai tenaga kesehatan. Hanya saja, ia tidak pernah berniat untuk menjadi perawat dan menjadi perawat merupakan pilihan terakhir baginya.

$\begin{array}{lr}\text { Sebenarnyar karena } & \text { keluarga mayoritas oom, } \\ \text { sepupu, perawat. } & \text { pebenarnyar pengen } \\ \text { kesmas, trus milih } & \text { keperawatan. Sebenernya } \\ \text { ga terlalu niat (Bia), }\end{array}$

Di samping itu, awalnya Bia memiliki sikap yang negatif terhadap profesi perawat karena ia menganggap bahwa nanti dirinya hanya akan menjadi pembantu dokter. Ia memaknai profesi perawat hanya sekedar memperhatikan kebersihan pasien, dan menyuntikkan obat.

Kalau awal banget aku ngeliat perawat pasti merasa pembantu dokter, trus ngebersihin BAB, ngemandiin, nyuntik-nyuntik obat doang, gitu-gitu, trus apa namanya, oo intinya banyak jadi pembantu dokter gitu 


\section{Peningkatan Kemampuan}

Selama bekerja di ruang intensif, partisipan merasakan adanya peningkatan kemampuan untuk terbiasa berpikir lebih kritis. Partisipan merasakan bahwa mereka terlatih untuk menganalisa perubahan sekecil apapun terhadap pasien.

Pokoknya lebih terlatih deh kritisnya, tau aja tanda-tanda nya kalo nafas pasien jelek udah tau terlatih gitu kritisnya. Misalnya jantungnya mau berhenti kita tau tanda-tandanya, nadi turun, kita tau trus pernafasannya, misalnya dia ga kuat kita tau (Ade).

Kerja di intensive care yang aku rasain jadi lebih kritis, karena kondisi pasien kurang stabil. Analisanya lebih dalam, kok dia bisa nyeri sih, kok tekanan darahnya turun sih. Aku masih harus belajar analisa lebih cepat (Bia).

Disitu (ICU) kita harus lengkap secara pemeriksaan, detil, kondisi kesadaran, tingkat pemeriksaan itu yang bikin kita harus bener-bener detil begitu, sampe cairan juga itu, apalagi kalo pas udah koma (Cita)

\section{Merasa Lelah}

Partisipan memandang profesi sebagai perawat merupakan pekerjaan yang melelahkan. Hal ini semakin terasa saat mereka ditempatkan di ruang intensif. Hal yang membuat pekerjaan tersebut selalu terasa melelahkan karena mereka dintuntut untuk terus menerus memperhatikan kondisi pasien bahkan pada saat jam istirahat. Jika kondisi pasien mengalami penurunan mereka terpaksa harus rela untuk menggunakan waktu istirahat untuk menyelamatkan pasien. Kondisi tersebut seringkali menimbulkan beban mental karena berurusan dengan keselamatan dan nyawa seseorang.

Pas ngejalanin pekerjaan sebagai perawat aku ngerasa capek. Kalau di
ICU itu kerja mungkin kalau bisa dibilang ga duduk, ya ga duduk. Dari mulai dinas pagi setengah sembilan hingga setengah 3, tujuh jam itu mungkin lima menit minum, 15 menit makan. Sisanya kita ke pasien (Ade).

Capek banget, aku sih suka dibilangin kalo dijalanin suka yaa enjoy gitu ya dinikmatin aja. Sejujurnya emang lebih capek, tergantung pembawaan masingmasing orang sih dia kayak gimana. Aku berusaha untuk menikmati tapi emang sebenarnya capek (Bia).

Beban pikiran mental di ICU mba. Soalnya berurusan dengan nyawa orang (Cita)

\section{Stres Kerja}

Kondisi pekerjaan yang sibuk seringkali menyebabkan partisipan merasakan tekanan kerja yang cukup tinggi. Stres kerja muncul karena berbagai macam faktor. Kondisi pasien yang tiba-tiba memburuk merupakan salah satu penyebab tingginya kecemasan. Hal ini disebabkan oleh tuntuta untuk fokus pada hal-hal detail. Hal tersebut membuat membuat dirinya menjadi semakin waspada. Dampaknya membuat mereka tidak memiliki waktu untuk makan bahkan sholat karena banyaknya tindakan yang harus dilakukannya.

Tantangan lain yang membuat Ade merasa stres adalah kekhawatiran terkait dengan potensi yang ia miliki dan teguranterguran yang seringali ia terima karena melakukan kesalahan. Meskipun baru bekerja, ia dituntut memiliki kompetensi seperti perawat lainnya. Oleh sebab itu, dalam kondisi lelahpun ia merasa harus belajar.

Sama halnya dengan Ade, Bia selalu merasa cemas di dua bulan pertama. Ia mengaku merasa stres setiap kali dihadapkan pada pekerjaan. Bentuk cemas termanifestasi dalam bentuk perilaku overthinking. Ia memprediksi dan 
membayangkan jumlah pasien yang masuk setiap harinya. Semakin ia membuat skenario terkait dengan jumlah pasien, semakin tinggi rasa cemas yang dialaminya.

Karena masih anak baru dan harus udah bisa, jadi kena omel lah iya. Dibilang mungkin mereka juga ada beban berbagi peran ya, ada yang emang cerewet segala macem dan menghadapi kakak-kakak yang cerewet, kalo ga kuat mungkin stres juga. Ga boleh lelet, ini salah! ini salah! Aduh, tantangan juga kalo ga kuat. Udah fisik capek, masih harus belajar (Ade).

Rasa cemas ketika kondisi pasien lagi drop, jadi lebih was-was, dampaknya aku jadi ga bisa makan karena tindakannya banyak (Bia).

Ketika awal ditempatin di HCU aku kaget, ketika awal-awal selama dua bulan, bulan pertama cemas dan stres. Setiap mau cemas pasti takut. Aku takut misalnya jumlah pasiennya berapa. Berapa ya pasiennya. Aduh full ga ya. Jadi aku cemas duluan (Cita).

Selain itu, perawatan di ruang intensif membutuhkan peralatan medis yang canggih. Namun demikian, fasilitas tersebut juga membuat biaya yang dikeluarkan oleh keluarga pasien cukup tinggi. Tingginya biaya perawatan membuat keluarga pasien tidak sanggup untuk melanjutkan perawatan dan membuat perawat terpaksa melepaskan alat medis dari tubuh pasien. Kondisi terburuk dari tindakan tersebut adalah kehilangan nyawa pasien. Pelepasan alat medis dari pasien, ternyata bukanlah hal yang mudah dilakukan bagi perawat terutama perawat yang masih baru.

Tampak adanya ketegangan, dimana adanya keinginan pribadi dan harapan yang besar agar pasien dapat kembali sembuh. Namun demikian, faktor eksternal seperti keluarga dan aturan rumah sakit membuat harapan tersebut tidak dapat sejalan dengan realita. Mereka menemui kasus dimana keluarga pasien meminta untuk menghentikan perawatan yang disebabkan oleh keterbatasan biaya. Selain itu, ada juga yang disebabkan oleh peraturan administrasi rumah sakit yang mengharuskan pemutusan perawatan akibat biaya yang tidak dapat ditanggung oleh pihak keluarga.

Mereka mengungkapkan bahwa adanya perasaan sedih dan emosional jika pasien tidak memeroleh pelayanan medis hingga sembuh. Meskipun demikian, mereka juga memahami bahwa keterbatasan ekonomi membuat keluarga tidak dapat melanjutkan perawatan. Sebagai perawat mereka merasa tidak dapat memberikan bantuan lebih jauh karena harus mematuhi aturan-aturan administratif dan menghormati keputusan keluarga. Kondisi tersebut menimbulkan dilema dalam mengambil keputusan.

Waktu itu aku pernah dapat satu kasus bapak-bapak dia masih bagus sebenarnya, cuma keluarganya ga bisa, jadi dari bpjs, bpjsnya mati. Dan ventilator itu bayarnya 5 juta dan mahal. Dia tiga hari berapa jam pokoknya ada hitungannya, 70 an tagihannya. Jadinya ga kuat. Bpjs pun ga bisa, akhirnya dia dipulang paksa, itu aku nganterin sambil ngebaging dalam ambulan. Saat ngelepas bagingan nya dia langsung ga bisa nafas. Aduh itu bener-bener. Mau balik ke ruangan ...... (partisipan merasa emosional dan matanya tampak berkaca-kaca sehingga tidak dapat menjelaskan apa yang ia rasakan (Ade).

Selain itu Ade juga menyatakan bahwa terdapat kondisi dimana tenaga medis tidak sampai hati untuk membuka peralatan yang terpasang di tubuh pasien. Oleh sebab itu mereka akan meminta pihak keluarga yang telah mengisi surat persetujuan untuk membuka sendiri peralatan medis dengan didampingi oleh tenaga medis. Tangisan dari 
pihak keluarga dan meninggalnya pasien karena kehilangan alat bantu untuk bertahan hidup sering kali membuat para perawat berada pada suasana yang menguras emosi dan paling dirasakan di ruang ICU.

Ooo akhirnya kita minta inform concent. Keluarga diminta ngisi dan tanda tangan sendiri, ibu lepas sendiri. Ga bisa perawat dokter tu, karena ga sampe hati. Akhirnya ya udah kita minta mereka minta. Ga lama mau turun ke bawah udah, pasiennya meninggal (Ade).

Kan udah dibilangin, kalo ibu cabut ga sampe lima menit pasien akan plus. Mereka nangis. Nah kasus yang seperti itu yang bikin menguras emosi. Paling kerasa di ICU (Ade).

\section{Duka atas Kehilangan}

Kehilangan pasien merupakan hal yang tidak dapat dihindarkan dari pekerjaan sebagai perawat di ruang intensif. Partisipan menganggap bahwa pasien merupakan bagian dari keluarga mereka. Kesedihan tersebut mungkin akan dirasakan jika suatu saat mereka juga kehilangan anggota keluarga. Terdapat peasaan sedih yang juga diiringi dengan perasaan bersalah karena tidak dapat mengembalikan hidup pasien. Rasa bersalah semakin kuat jika hubungan yang terjalin dengan keluarga pasien cukup hangat.

Jelas sedih, saya menganggap pasien itu seperti keluarga sendiri. Kalo misalnya meninggal, ya sedih seperti nanti keluarga saya meninggal kayak gini rasanya. Ya kehilangan juga (Cita)

Sedih, aku sempat, apalagi kalo keluarganya baik jadi terbawa emosional gitu, kayak apa ya, masih suka ada rasa ya Allah kok udah waktunya, jadi ada rasa bersalah gitu, tapi ga bisa ngehidupin lagi kan (Bia).
Selain itu, juga terdapat perasaan marah terhadap keluarga yang tiba-tiba memutuskan untuk menghentikan perawatan intensif yang menyebabkan pasien meninggal. Perasaan marah semakin menguat karena tidak dapat memberikan pertolongan yang lebih kepada pasien.

Kadang marah juga karena tau tibatiba, soalnya semalem anaknya yang ditunggu tunggu udah datang, dia yang memutuskan mengganti perawatan bapaknya. Udah bapaknya itu aja minimal terapi, trus kondisinya langsung jelek segala macem dan meninggal gitu. Ada rasa-rasa yang kayak gitu. Marah gimana ya harusnya, pak tahan dong, lo harus pertahanin dulu jangan dikasih perawatan kayak gitu. Ya kita sebenarnya bisa apa, yang buat keputusan kan pasien dan keluarga gitu. Sedih, trus baper (Ade).

\section{Takut Kehilangan Empati}

Seringkali dihadapkan pada rasa sakit yang dihadapi pasien dan rasa lelah saat bertugas tidak jarang partisipan merasakan rasa empati yang tidak konsisten. Adakalanya mereka kehilangan rasa empati sehingga mengabaikan kondisi psikologis pasien dan keluarganya.

Berada di ruang ICU membuat Ade merasa tidak menyadari kapan rasa empati tinggi dan kapan ia harus professional. Pada saat empati tinggi, dirinya akan berusaha menyemangati pasien untuk tidak menyerah. Akan tetapi, jika rasa professional yang lebih mendominasi maka ia akan secara gamblang menyatakan perawatan tidak akan dapat membantu pasien. Pada dasarnya Ade mengalami rasa takut jika empatinya akan memudar terhadap pasien.

Sama hal nya dengan Ade, Bia kadang merasakan empatinya menurun tapi tidak sampai hilang. Kalaupun agak menurun biasanya partisipan akan mencari kegiatan lain untuk melakukan refreshing diri. Cita menganggap bahwa empati 
merupakan hal yang tidak boleh lepas dari perawat, karena menurutnya hal itu yang menjadi dasar untuk selalu dapat memberikan yang terbaik. Meskipun demikian, ia tidak menyangkal bahwa memang ada saat-saat tertentu dimana empati mengalami penurunan. Jika hal tersebut terjadi, Cita berusaha untuk membayangkan jika dirinya merupakan bagian dari keluarga pasien.

Itulah, pusing. Itu dia sebenernya ga berasa kapan empati tinggi, ada kita yang mengutamakan professional kalo lagi bagus kita arahkan untuk tidak berempati gitu-gitu. Jadi tergantung perawatnya itu mah. Kalo emang empati nya lagi tinggi kita akan bantu semangat terus dan bantu terus jangan nyerah, kita CPR segala macem. Kalo professional lagi kritis soal ke medis, nah muncul ibu ini udah ga bisa gitu. Gitu gitu. Mood swing banget. Rasa seperti itu aku takut kehilangan, empatinya luntur gitu (Ade).

Kalo aku belum sampe hilang empatinya. Mungkin ada empatinya menurun, tapi aku pake koping. Aku mesti ngerefresh diri (Bia).

Bagi saya empati iya bisa terkikis karena udah terbiasa. Tapi ga segitu banyaknya. Kalo saya sih memandangnya ga akan terkikis semuanya.... Saya balikin lagi, jika saya menempatkan diri sebagai keluarga (Cita).

\section{Perasaan Cemas dan Takut Tertular Penyakit yang Berbahaya \\ Partisipan merasa cemas dan takut} akan tertular penyakit berbahaya. Partisipan memandang bahwa pekerjaan di ruang ICU sangat rentan akan terpapar penyakit menular karena kondisi ruangan yang tertutup. Bagi Ade, penyakit yang sangat membuat ia cemas jika terdapat pasien dengan riwayat HIV/AIDS dan Tuberculosis. Ade melihat bahwa pada pasien HIV dimana penularan melalui cairan tubuh akan sangat berbahaya jika ada luka. Sementara itu, jika penyakit yang penularannya melalui udara maka hal itulah yang membuat adanya rasa takut apalagi jika pasien tersebut ditempatkan di timnya.

Ruang ICU tertutup kan, jadi high risk buat infeksi. Kayak pasien $T B$, HIV/AIDS segala macem, serem, takut tuh banyak. HIV itu kan penularannya melalui kontak cairan tubuh dan itupun kalaupun kita ada luka, baru high riski. Nah kalo penularannya lewat udara, kalo batuk satu ruangan terkontaminasi. Saat itu kebagian di shift aku, dan tim aku pula tempat kosongnya, nah disitu ada rasa takut (Ade).

Hal tersebut juga dirasakan oleh Cita yang saat ini ia bertugas di ruang isolasi pasien COVID-19. Ia tidak menyangkal bahwa rasa cemas tertular selalu menghantui dirinya setiap kali bertugas. Perasaan yang dirasakannya campur aduk sehingga membuat dirinya stres. Konflik utama yang ia alami adalah ketakutan jika dirinya terpapar dan menulari keluarganya.

Campur aduk. Takut, ga karuan, cemas, stres, stres nya takut menulari keluarga (Cita).

\section{Motivasi Tetap Mengabdi sebagai Perawat}

Meskipun partisipan memiliki pandangan negatif terhadap profesinya, namun hal tersebut tidak serta merta membuat mereka mundur dari profesi tersebut. Meskipun dihadapkan pada berbagai konflik dan tantangan terdapat upaya untuk memberikan yang terbaik kepada pasien. Ade mengungkapkan bahwa ia memiliki minat di bidang kegawat daruratan sehingga membuat dirinya masih dapat menikmati pekerjaanya. Selain itu, ia ingin menjadi perawat yang baik untuk memenuhi harapan ayahnya sepenuhnya.

Jadi pengen aja jadi perawat yang benar. Pasti ayahku melihat di suatu 
tempat... Aku dari awal ditempatin di ICU dan semenjak kuliah emang suka (Ade).

Cita mengungkapkan bahwa terlepas dari segala konflik dan emosi negatif yang muncul, terdapat rasa puas dan bangga saat memberi pertolongan dan menyelamatkan nyawa pasien.

Saya pernah dulu, ada pasien yg mau meninggal, alhmadulillah bisa ditolong. Jadi gini ya rasanya bisa menolong orang rasanya bangga (Cita).

Disamping itu mengambil libur sebentar membantu mereka untuk berjarak dengan stres dan cemas dan sangat membantu dalam menetralkan kondisi mereka.

Yang enaknya di ICU untuk maintenance kayak gitu bagus. Misalnya kita minta jadwal istirahat dua hari pasti dikasih. Jadi kita ada jatah libur ekstra namanya satu tahun 16 hari di luar cuti. Jadi kita bisa minta. . Itu berguna banget tuh (Ade).

Kan kita ada waktu libur ya, nah waktu libur itu aku gunain buat nonton, atau aku pergi kemana gitu ya jadi waktu masuk dinas lagi jadi terefreshkan (Bia)

Saya biasanya main, kumpul, dan ngegame (Cita).

Selain itu, terdapat tema khusus yang dialami oleh Cita yang saat ini bertugas di ruang isolasi COVID-19.

\section{Takut Didiskriminasi oleh Masyarakat karena Menangani COVID-19}

Semenjak COVID-19 ditetapkan sebagai pandemi, Cita memiliki ketakutan menjadi target diskriminasi dari tetangganya. Namun, pada dasarnya ia lebih mengkhawatirkan keluarganya yang seharihari tinggal di rumah. Ia juga takut jika diusir oleh masyarakat sekitar. Hal tersebut membuat partisipan mencari kontrakan baru untuk berjaga-jaga jika kejadian pengusiran benar-benar terjadi. Namun, tidak ada satupun pemilik kontrakan yang mau menerima dirinya.

.....yang lebih stres dari masyarakat. Yaa, sampai sekarang masyarakat melihat tenaga kesehatan yang covid dijauhi. Saya kan tinggal sama ibu di kontrakan. Kalau saya pulang dan masyarakat tahu, takutnya saya diusir. Soalnya nyari tempat tinggal susah. Kemaren saya nyari trus ditolak yg punya takut tertular (Cita).

\section{Marah, Merasa Diperlakukan Tidak Adil oleh Masyarakat}

Cita merasa marah terhadap masyarakat yang ada di sekitarnya karena diperlakukan tidak adil. Bentuk perlakuan tidak adil yang ia terima berupa penutupan jalan menuju rumahnya. Partisipan merasa bahwa pekerjaan yang ia lakukan bukanlah suatu pekerjaan yang merugikan orang lain, justru sebaliknya yaitu merawat orang-orang yang sakit. Ditambah lagi, tindakan masyarakat menghambat dirinya untuk memenuhi kebutuhan keluarganya. Perasaan marah diungkapkan secara langsung kepada tokoh masyarakat yang dianggap tidak memberikan keputusan yang bijaksana. Selain itu, juga terdapat orang-orang yang memprovokasi tindakan diskriminasi tersebut.

Rumah saya di pojok dekat sawah. Itu jalan cuman satu dan katanya mau di lockdown, trus saya mau lewat mana. Saya bilang ke pak RT dan saya marah. Biasanya setelah jaga, saya kan beliin makan buat ibu saya sahur, trus kalo jalan ditutup saya mau lewat mana. Dari situ saya marah-marah. Ada provokator juga, saya sampe turun tangan buat ikut covid kan demi kalian, saya gituin. Misalnya kalo sетиа perawat dilockdown gimana. Persepsi orang itu kan nularin (Cita). 


\section{Berdamai dengan Ruang Isolasi COVID- 19}

Meskipun pada awal bertugas Cita menyatakan adanya kekhawatiran akibat merawat pasien COVID-19, namun saat ini ia mengungkapkan mulai terbiasa dengan kondisi saat ini. Menurutnya, yang membuat perasaan khawatir adalah berita yang tidak jelas kebenarannya. Namun demikian, setelah memiliki pengalaman dan terbiasa dengan kondisi yang dihadapi, partisipan

Tabel 1

Rangkuman Pengalaman Antar Partisipan mulai dapat beradaptasi dan berdamai dengan tugas yang diemban saat wabah masih berlangsung.

Ibaratnya saat ini saya sudah mulai bersahabat dengan keadaan. Kalau awal-awalnya memang takut. Sekarang lebih tau bagaimana kondisi di lapangan dan jadi lebih tau menanganinya (Cita).

\begin{tabular}{|c|c|}
\hline Tema & Pemaknaan \\
\hline Motivasi tetap menjadi perawat & $\begin{array}{l}\text { - Memenuhi harapan orang tua } \\
\text { - Perasaan senang saat memberikan } \\
\text { pertolongan }\end{array}$ \\
\hline Merasa Lelah & $\begin{array}{l}\text { - Tidak adanya waktu istirahat yang memadai } \\
\text { - Bekerja di ruang intensif jauh lebih } \\
\text { melelahkan } \\
\text { - Selalu merasa terbebani }\end{array}$ \\
\hline Peningkatan kemampuan & $\begin{array}{l}\text { - Terbiasa memperhatikan tanda fisik pasien } \\
\text { - Lebih kritis karena kondisi pasien yang } \\
\text { tidak stabil } \\
\text { - Terbiasa melakukan pemeriksaan secara } \\
\text { detil. }\end{array}$ \\
\hline $\begin{array}{l}\text { Stres kerja } \\
\text { - Mengalami rasa cemas } \\
\text { - Dilemma atas tindakan yang berkaitan } \\
\text { dengan kehidupan pasien }\end{array}$ & $\begin{array}{l}\text { - } \quad \text { Tidak percaya diri, merasa tidak mampu } \\
\text { - } \quad \text { Mengalami overthinking } \\
\text { - Waktu istirahat yang minim }\end{array}$ \\
\hline - Empati yang memudar & $\begin{array}{l}\text { Empati memudar saat rasa profesionalitas } \\
\text { meningkat } \\
\text { Terkikisnya empati karena mulai terbiasa } \\
\text { karena terpapar rasa sakit. }\end{array}$ \\
\hline - Dihadapkan pada proses berduka & $\begin{array}{l}\text { - } \text { Rasa sedih seperti kehilangan keluarga } \\
\text { - } \text { Rasa sedih yang intens karena memiliki } \\
\text { hubungan yang hangat dengan keluarga } \\
\text { pasien } \\
\text { - Marah tidak dapat melakukan suatu } \\
\text { tindakan yang berarti saat kehilangan pasien }\end{array}$ \\
\hline Cemas tertular penyakit menular & $\begin{array}{l}\text { - Khawatir tertular melalui kontak dan } \\
\text { kondisi ruangan yang tertutup. } \\
\text { - Cemas jika turut menginfeksi keluarga }\end{array}$ \\
\hline Motivasi tetap mengabdi & $\begin{array}{l}\text { - Keinginan untuk menjadi perawat yang baik } \\
\text { dan sesuai dengan harapan orang tua } \\
\text { - Perasaan puas dan bangga saat pasien } \\
\text { selamat dari kematian. }\end{array}$ \\
\hline
\end{tabular}




\begin{tabular}{lll}
\hline \multicolumn{2}{c}{ Tema Khusus pada Perawat yang sedang Bekerja di Ruang Isolasi COVID 19 } \\
\hline Takut diskriminasi & $\bullet$ & Takut diusir oleh tetangga \\
\hline Diperlakukan tidak adil & $\bullet$ & Rasa marah karena dikucilkan karena merawat \\
& pasien COVID \\
\hline Berdamai & $\bullet \begin{array}{l}\text { Mulai terbiasa dengan kondisi dan pekerjaan di } \\
\text { ruang isolasi COVID }\end{array}$ \\
\hline
\end{tabular}

Berdasarkan hasil analisis tema, terdapat beberapa tema yang memiliki kesamaan di antara partisipan. Tema pertama yaitu terkait dengan pemilihan untuk menjalani profesi sebagai perawat. Pilihan menjadi sebagai perawat pada mulanya tidak berasal dari keinginan sendiri, tetapi karena motivasi ekternal terutama harapan dari orang terdekat.

Partisipan memiliki pandangan bahwa menjalani rutinitas sebagai perawat merupakan hal yang cukup melelahkan karena kewajiban untuk terus menerus memantau pasien apalagi mereka harus bertugas di ruang ICU. Semua partisipan mengungkapkan bahwa terlalu banyak memberikan pelayanan kemanusian seringkali mengancam rasa empati. Ada perasaan takut jika rasa empati tersebut terkikis sehingga mereka kehilangan rasa berbuat baik kepada pasien. Pekerjaan di ruang intensif yang seringkali berhadapan dengan kondisi pasien yang tidak menentu mengharuskan mereka untuk kritis dan teliti. Partisipan merasa hal tersebut yang seringkali menimbulkan kecemasan dan kelelahan bagi mereka. Tema mengenai duka dan perasaan bersalah muncul pada semua partisipan. Dua partisipan menyatakan adanya perasaan marah dan rasa bersalah karena keterbatasan wewenang.

Beberapa tema cukup berbeda dan menonjol pada partisipan Cita dimana saat dilaksanakan wawancara dirinya ditugaskan di ruang isolasi COVID-19. Bekerja menjadi perawat di ruang isolasi menimbulkan konflik karena ia harus menjalankan kewajiban dan diiringi dengan perasaan khawatir jika tertular dan menularkan kepada orang di sekitarnya. Tidak hanya itu, pekerjaan tersebut menjadi bertambah berat saat dirinya menjadi target diskriminasi dari warga sekitar. Partisipan dan keluarganya menerima perlakukan yang tidak menyenangkan karena dianggap menularkan virus kepada masyakat. Kondisi tersebut membuat dirinya cemas dan marah karena perbuatan baik yang ia lakukan tidak dihargai.

\section{DISKUSI}

Penelitian ini bertujuan untuk melihat pemaknaan perawat terhadap pekerjaannya di ruangan intensive care dan ruang isolasi pasien COVID-19. Berdasarkan -analisis tema, diperoleh tujuh tema besar. Tematema tersebut didominasi oleh tema pengalaman negatif diantaranya adalah menjadi perawat bukan pilihan personal, pekerjaan sebagai perawat dipersepsi melelahkan, perasaan stres dan cemas dengan pekerjaan di ruangan intensif, rasa takut kehilangan empati, menjadi lebih kritis, perasaan duka atas kehilangan, dan rasa cemas akan penyakit menular. Terdapat satu tema positif yaitu motivasi mereka untuk terus menjalani profesi sebagai perawat.

Dari pengalaman tiga orang perawat di ruang intensif dan ruang isolasi COVID-19, tampak bawa pilihan menjadi perawat bukanlah didasari oleh motivasi intrinsik, tetapi karena motivasi ekstrinsik, khususnya orangtua dan keluarga. Dua orang partisipan tidak memiliki awal yang positif tentang profesi perawat, lebih melihat hal-hal yang negatif. Dave, dkk (2011) menyatakan bahwa perawat yang memiliki motivasi 
ekstrinsik memiliki kepuasan yang lebih rendah terhadap pekerjaannya karena hanya termotivasi oleh reward eksternal seperti gaji, promosi, dan kurang termotivasi untuk merawat pasien. Setelah memasuki dunia kerja persepsi negatif tersebut ditemui secara nyata dimana menjadi perawat dianggap sebagai pekerjaan dengan beban kerja yang berat.

Hal ini juga tidak terlepas dari beban dan jumlah jam kerja yang cukup panjang. Berdasarkan Dagget dkk. (2016), jumlah jam kerja perawat dapat dapat mencapai 12 jam khususnya di rumah sakit, harus memiliki tingkat kewaspadaan yang tinggi, dan meyakinkan bahwa pasien merasa nyaman di lingkungan rumah sakit. Selain itu, pekerjaan di ruang intensif menuntut mereka untuk dapat membuat berbagai rencana untuk terhadap berbagai kemungkinan yang akan terjadi pada pasien (Trousselard dkk., 2016). Dengan demikian, mereka menganggap pekerjaan perawat itu berat, maka bisa dimengerti bahwa dalam pengalaman mereka sebagai perawat lebih banyak tema yang bersifat emosional seperti perasaan tidak setara, cemas, stres, takut, kehilangan empati, merasa bersalah dan marah karena tidak berdaya dalam membuat keputusan untuk melanjutkan perawatan pasien karena permintaan keluarga.

Di samping itu, munculnya tematema emosional juga disebabkan oleh kurangnya waktu istirahat yang dimiliki oleh partisipan. Ketidakpastian mengenai kondisi pasien di masa yang akan datang seringkali menimbulkan perasaan cemas dan khawatir pada partisipan. Selama bekerja di ruang intensif partisipan merasa tidak memiliki waktu luang sehingga untuk memenuhi kebutuhan dasar seperti makan pun dirasa sangat sulit. Hal ini dikarenakan tanggung jawab yang besar dan prosedur yang ketat dalam melakukan monitoring terhadap pasien. Kondisi ini seringkali menyebabkan munculnya compassion fatigue yang menjadi salah satu penyebab menurunnya rasa empati. Adapun penyebab munculnya compassion fatigue salah satunya karena mereka sering terpapar akan rasa sakit yang dimiliki pasien. Hal ini menyebabkan berpindahnya distress emosional yang dirasakan pasien terhadap perawat yang berlangsung dalam waktu yang cukup lama sehingga menyebabkan perawat merasakan kelelahan secara emosional (Sacco dkk., 2015). Partisipan menyatakan bahwa menurunnya empati disebabkan oleh rasa lelah ditambah dengan beban kerja di ruang intensif yang membuat mereka harus tetap siaga kapanpun. Menurut Weigl dkk. (2016) menurunnya empati diawali dengan proses depersonalisasi. Depersonalisasi membuat perawat tidak lagi menghiraukan perasaan subjektif pasien serta terjadinya pengabaian atas kualitas pelayanan yang diberikan (Maslach dkk., 2001). Hal ini tampak dirasakan oleh partisipan Ade, dimana saat empatinya menurun kepeduliannya terhadap rasa sakit pasien menjadi berkurang dan ia tampak cukup pesimis dengan kondisi pasien.

Selain itu, pandangan terhadap ketidaksetaraan di dalam profesi menjadi salah satu hal yang menjadi fokus partisipan sebelum memasuki dunia keperawatan. Hal ini dapat dipahami karena seringkali perawat dianggap sebagai bawahan yang menunggu perintah dari dokter dan tidak memiliki otoritas untuk membuat keputusan (Fagin \& Garelick, 2004). Hal ini menjadi isu terhadap kepuasan kerja dimana mereka tidak memiliki otoritas dalam mengambil keputusan medis layaknya dokter sehingga terdapat perasaan bersalah dan gagal saat kondisi pasien memburuk (Dagget dkk., 2016).

Pengalaman emosional berupa duka atas kehilangan pasien turut menjadi tantangan dalam menjalankan tugas secara profesional. Pada kondisi tertentu partisipan merasa sulit untuk melepas kematian pasien. Hal ini sejalan dengan studi yang dilakukan oleh Shorter dan Stayt (2009) yang menyatakan bahwa perasaan berduka tidak dapat dihindari dari pekerjaan sebagai perawat di ruang intensif. Namun demikian, Hamric dan Blackhall (2007) mengungkapkan terdapat kondisi-kondisi dimana perawat tidak dapat memberikan 
pertolongan secara maksimal. Pada penelitian ini ditemukan bahwa partisipan rasa dan bersalah karena tidak dapat melakukan apapun jika pihak keluarga memutuskan untuk menghentikan perawatan.

Hal lain yang menjadi keresahan partisipan dalam penelitian ini berupa rasa takut tertular penyakit berbahaya. Partisipan menyadari bahwa selalu ada sikap waspada atas penyakit yang dapat menular terutama saat bekerja di ruangan intensif. Sebagai helping profession, perawat tidak dapat memilih pasien mana yang mesti ditangani dan harus menerima tanggung jawab dengan sukarela. Kondisi ini seringkali menghantui partisipan saat menerima pasien yang memiliki riwayat penyakit menular di ruang intensif. Saat wabah SARS, banyak dari petugas dan perawat ruang intensif yang tertular meskipun telah menggunakan pelindung diri (Scales dkk., 2003). Tidak jauh berbeda dengan kondisi wabah COVID-19 yang muncul akhir-akhir ini. Hal ini turut menimbulkan munculnya permasalahan baru terkait kesehatan mental bagi perawat. Secara umum, emosi negatif muncul di awal masa bertugas (Nemati dkk., 2020). Sebuah studi mengemukakan tenaga medis menunjukkan munculnya gejala psikologis seperti depresi, kecemasan dan gangguan tidur selama COVID-19 (Spoorthy, 2020). Hal ini dikarenakan keterbatasan informasi ilmiah terkait dengan sifat virus tersebut. Partisipan Cita merasakan kegelisahan muncul sebagai akibat dari berbagai informasi yang simpang siur terkait dengan ancaman virus tersebut. Rasa khawatir yang dialami oleh partisipan tidak hanya mengenai dirinya sendiri, tapi juga terkait dengan keluarga yang berinteraksi langsung dengannya. Hal ini sejalan dengan studi yang dilakukan oleh Nemati dkk. (2020) yang menyatakan bahwa perasaan khawatir menjadi pemicu konflik batin dimana terdapat rasa takut jika menjadi media penularan virus kepada anggota keluarga. Hal yang sama juga terjadinya pada saat pandemi akibat virus Ebola dan MERS-CovStudi, perawat lebih merisaukan keluarga yang serumah dengan mereka (Lee dkk., 2005).

Kondisi lain yang memperparah buruknya kesehatan mental partisipan saat bertugas di ruang isolasi COVID-19 adalah adanya diskriminasi dan penolakan masyarakat. Penolakan yang dialami dapat menimbulkan munculnya masalah baru seperti kesepian, ketakutan bertemu dengan orang lain, dan berbagai masalah psikologis lainnya. Meskipun seringkali merasa terancam akan bahaya, proses adaptasi secara tidak langsung berdampak positif. Perawat mulai terbiasa dengan berbagai prosedur yang ada serta pengalaman yang diperoleh selama bertugas secara perlahan dapat mengurangi emosi negatif. Sun dkk. (2020) mengungkapkan pengalaman yang telah mereka lalui perlahan-lahan membangun rasa percaya diri. Penelitian di atas sejalan dengan apa yang dirasakan oleh partisipan dimana ia mulai berdamai dengan kondisi saat ini karena pengalaman langsung yang diperolehnya selama bertugas di ruang isolasi.

Di satu sisi, masih ada semangat untuk mengabdi dan melakukan tugasnya dengan baik, namun mereka juga menyadari adanya keterbatasan diri sebagai manusia biasa rasa lelah secara fisik dan mental, ketidak mampuan mengendalikan faktor eksternal seperti kondisi penyakit pasien dan kondisi ekonomi keluarga pasien serta ketakutan terhadap tertular penyakit dan perlakuan tidak baik dari masyarakat disekitar tempat tinggalnya sehubungan dengan pekerjaannya di ruang isolasi COVID-19. Wang dkk. (2015) menyatakan bahwa perawat yang memaknai perannya sebagai bagian dari pekerjaan dalam menolong orang akan merasa lebih puas dan menyenangi pekerjaannya. Selain itu, salah satu partisipan menyatakan bahwa passion dan kekompakan tim di tempat kerja membuatnya dapat menikmati pengabdian profesionalnya. Perawat yang sedang bekerja di ruang isolasi COVID-19 menyatakan bahwa dirinya selalu mendapatkan kepuasan dari setiap pasien yang selamat. 


\section{SIMPULAN}

Berdasarkan pada penelitian di atas diperoleh secara garis besar bahwa partisipan melaporkan adanya perasaan dan emosi negatif yang cukup intens di tempat kerja. Hal ini mengarah pada munculnya stres sebagai akibat dari tuntutan dan tanggung jawab yang besar terkait dengan menyelamatkan nyawa. Berdasarkan pemaknaan masing-masing partisipan, mereka sama-sama memaknai profesinya sebagai pekerjaan yang penuh dengan tantangan. Tantangan tersebut dipersepsi sebagai beban dalam menjalani pekerjaan. Ketakutan kehilangan empati merupakan tantangan yang paling disadari. Semua partisipan memaknai bahwa empati merupakan hal utama dalam memahami kondisi emosional pasien. Meskipun demikian, penelitian ini mengungkapkan secara khusus bahwa penyebab munculnya emosi negatif dan penyebab munculnya masalah psikologis sangat bervariasi antar partisipan. Hal ini tidak dapat ditangkap oleh penelitian kuantitatif. Hal ini dapat menjadi pertimbangan dalam pemberian intervensi psikologis bagi perawat sesuai dengan kebutuhan dan tepat sasaran.

Keterbatasan pada penelitian ini yaitu tidak menggali lebih dalam mengenai pengalaman positif yang dialami oleh perawat. Hal ini akan menjadi lebih menarik dan memperoleh pemaknaan yang lebih utuh. Di samping itu, dari segi metode, jumlah partisipan tergolong cukup kecil untuk populasi perawat yang bekerja di ruang intensive care. Penambahan jumlah partisipan akan lebih dapat memberikan informasi dan hasil yang lebih mendalam mengenai fenomena kondisi psikologis yang dialami oleh perawat.

\section{SARAN}

Untuk menambah kedalaman dari penelitian sejenis, penelitian selanjutnya dapat menggali lebih dalam pemaknaan positif yang mereka alami. Hal ini dapat mengungkapkan secara lebih komprehensif alasan mereka memutuskan untuk tetap mengabdi dan menjalankan profesinya.

Secara praktis penelitian ini dapat memberikan gambaran kondisi mental perawat yang dilihat dari kacamata subjektif. Mereka membutuhkan perhatian terutama dalam memperoleh kesejahteraan psikologis dalam bekerja. Instansi yang berkaitan dapat memberikan intervensi psikologis untuk mencegah munculnya masalah psikologis yang lebih berat.

\section{DAFTAR PUSTAKA}

Adriaenssens, J., De Gucht, V., \& Maes, S. (2012). The impact of traumatic events on emergency room nurses: Findings from a questionnaire survey. International Journal of Nursing Studies, 49(11), 1411-1422.

Creswell, J. W., Hanson, W. E., Clark Plano, V. L., \& Morales, A. (2007). Qualitative research designs: Selection and implementation. The Counseling Psychologist, 35(2), 236-264.

Dagget, T., Molla, A., \& Belachew, T. (2016). Job related stres among nurses working in Jimma Zone public hospitals, South West Ethiopia: a cross sectional study. BMC Nursing, 15(1), $1-10$.

Dave, D. S., Dotson, M. J., Cazier, J. A., Chawla, S. K., \& Badgett, T. F. (2011). The impact of intrinsic motivation on satisfaction with extrinsic rewards in a nursing environment. Journal of Management \& Marketing in Healthcare, 4(2), 101-107.

Fagin, L., \& Garelick, A. (2004). The doctor-nurse relationship. Advances in Psychiatric Treatment, 10(4), 277-286.

Faseleh-Jahromi, M., Moattari, M., \& Peyrovi, H. (2014). Iranian nurses' perceptions of social responsibility: A qualitative study. Nursing Ethics, 21(3), 289-298. 
Hamric, A. B., \& Blackhall, L. J. (2007). Nurse-physician perspectives on the care of dying patients in intensive care units: collaboration, moral distress, and ethical climate. Critical Care Medicine, $35(2), 422-429$.

Hoff, T., Carabetta, S., \& Collinson, G. E. (2019). Satisfaction, burnout, and turnover among nurse practitioners and physician assistants: a review of the empirical literature. Medical Care Research and Review, 76(1), 3-31.

Langdridge, D. (2007). Phenomenological psychology: Theory, research and method. Pearson Education.

Lee, S.-H., Juang, Y.-Y., Su, Y.-J., Lee, H.L., Lin, Y.-H., \& Chao, C.-C. (2005). Facing SARS: psychological impacts on SARS team nurses and psychiatric services in a Taiwan general hospital. General Hospital Psychiatry, 27(5), 352-358.

Mantalea, V (19 Maret 2021). PPNI: 20 Perawat di Indonesia Meninggal Melayani Pasien COVID-19. Kompas. https://megapolitan.kompas.com/read/ 2020/05/19/05582081/ppni-20perawat-di-indonesia-meninggaldunia-dalam-tugas-melayanipasien?page $=$ all\#page 2 .

Maslach, C., Schaufeli, W. B., \& Leiter, M. P. (2001). Job burnout. Annual Review of Psychology, 52(1), 397-422.

Myhren, H., Ekeberg, Ø., \& Stokland, O. (2013). Job satisfaction and burnout among intensive care unit nurses and physicians. Critical Care Research and Practice, 2013.

Nemati, M., Ebrahimi, B., \& Nemati, F. (2020). Assessment of Iranian nurses' knowledge and anxiety toward COVID-19 during the current outbreak in Iran. Arch Clin Infect Dis,
15(COVID-19), e102848.

Pradas-Hernández, L., Ariza, T., GómezUrquiza, J. L., Albendín-García, L., De la Fuente, E. I., \& Canadas-De la Fuente, G. A. (2018). Prevalence of burnout in paediatric nurses: A systematic review and meta-analysis. PloS One, 13(4), e0195039.

Sacco, T. L., Ciurzynski, S. M., Harvey, M. E., \& Ingersoll, G. L. (2015). Compassion satisfaction and compassion fatigue among critical care nurses. Critical Care Nurse, 35(4), 3242.

Scales, D. C., Green, K., Chan, A. K., Poutanen, S. M., Foster, D., Nowak, K., Raboud, J. M., Saskin, R., Lapinsky, S. E., \& Stewart, T. E. (2003). Illness in intensive care staff after brief exposure to severe acute respiratory syndrome. Emerging Infectious Diseases, 9(10), 1205.

Shorter, M., \& Stayt, L. C. (2009). Critical care nurses' experiences of grief in an adult intensive care unit. Journal of Advanced Nursing, 66(1), 159-167.

Spoorthy, M. S. (2020). Mental health problems faced by healthcare workers due to the COVID-19 pandemic-A review. Asian Journal of Psychiatry, 51(April), 2018-2021. https://doi.org/10.1016/j.ajp.2020.1021 19.

Stone, P. W., Clarke, S. P., Cimiotti, J., \& Correa-de-Araujo, R. (2004). Nurses' working conditions: implications for infectious disease. Emerging Infectious Diseases, 10(11), 1984.

Sun, N., Wei, L., Shi, S., Jiao, D., Song, R., Ma, L., Wang, H., Wang, C., Wang, Z., \& You, Y. (2020). A qualitative study on the psychological experience of caregivers of COVID-19 patients. 
American Journal of Infection Control, 48(6), 592-598.

Tajvar, A., Saraji, G. N., Ghanbarnejad, A., Omidi, L., Hosseini, S. S. S., \& Abadi, A. S. S. (2015). Occupational stres and mental health among nurses in a medical intensive care unit of a general hospital in Bandar Abbas in 2013. Electronic Physician, 7(3), 110811013.https://doi.org/10.14661/2015.1 108-1113.

Trousselard, M., Dutheil, F., Naughton, G., Cosserant, S., Amadon, S., Dualé, C., \& Schoeffler, P. (2016). Stres among nurses working in emergency, anesthesiology and intensive care units depends on qualification: a Job Demand-Control survey. International Archives of Occupational and Environmental Health, 89(2), 221-229.

Wang, S., Liu, Y., \& Wang, L. (2015a). Nurse burnout: personal and environmental factors as predictors. International Journal of Nursing Practice, 21(1), 78-86.

Wang, S., Liu, Y., \& Wang, L. (2015b). Nurse burnout: Personal and environmental factors as predictors. International Journal of Nursing Practice, 21(1), 78-86. https://doi.org/10.1111/ijn.12216.

Weigl, M., Stab, N., Herms, I., Angerer, P., Hacker, W., \& Glaser, J. (2016). The associations of supervisor support and work overload with burnout and depression: A cross-sectional study in two nursing settings. Journal of Advanced Nursing, 72(8), 1774-1788. 